\title{
Science Education for Sustainable Development in Nigeria: Challenges and Prospects
}

Okoli Stella Obianuju

Obiajulu Angela N

Ella Francis A.

School of Sciences

Federal College of Education (Technical), Umunze-Anambra State, Nigeria

\section{Doi:10.5901/ajis.2013.v2n6p159}

\begin{abstract}
Sustainable development in Nigeria can be actualized through science education. This paper looked at the myths and the benefits of science education, roles of the science teachers, the challenges and prospects of science education. The paper also recommends among others that the government should provide necessary science research equipment in the research institutes so that Nigerian scientists can carry out research work without tears especially as regards to the economy of the country and also Science teachers should be well paid so that they can put in their best in teaching the students.
\end{abstract}

\section{Introduction}

For any nation including Nigeria to attain sustainable development, there is need to recognize science education as a priority area of education for her citizens (Ogunmade, 2006).

Science is derived from Latin word "scientia" which means what is to know, what is a fact, truth or certain. Science according to Onah (2003) is the bedrock upon which any nation can be built. This means that no country can be globally recognized without talking about its scientific advancements. Mbajiorgu (2003) views science as an act of doing and is more concerned with various investigative processes and activities with regards to developing, acquiring and controlling knowledge, skills, capacity and attitude about the natural factors of the environment. This implies that science is a way of knowing the facts, theories among others.

Science education is described by Pember and Humbe (2009) as a process of teaching or training especially, in school to improve one's knowledge about environment and to develop one's skill of systematic inquiry as well as natural attitudinal characteristics. Science education has been recognized worldwide as a pre-requisite in technological development. Science education involves the study of science in depth and in addition, educational knowledge and concepts are learnt and verified. No country can be globally recognized without talking about its scientific advancements. According to Lewis (1985) science education identifies natural phenomena appropriate to child interest and skills. Science education also equips teachers, learners and the society with knowledge, skills, equipment and freedom to perform noble task useful for improving socioeconomic standard. In addition he added that science education courses are designed to produce capable scientists who contribute meaningfully to academic excellence of the society to raise the economic level of nations. 
Despite the importance of science education to national development, Nigeria lacked sustainable science education since its independence and as a result, science education has not been able to move the country into industrialization and above poverty level. According to Momeke (2007), science education has failed to produce skilled human resources needed for transformation into national prosperity. This implies that most of Nigeria's development in the direction of modernization has been haphazard leading to acquisition of obsolete technology. Sustainable science education development therefore represents a catalytic process for social educational, training and public awareness - the values, behaviour and lifestyles required for a sustainable future.

\title{
2. Myths of Science Education
}

Some of the Myths of science education identified by Bower and Pire (2009) included:

\subsection{Large percentage of teachers are incompetent:}

Nada (2008) observed that the status of competency in secondary school science education in Nigeria appears very low. He went ahead to report that majority of teachers who are already in the system seem to lack initiatives and skills that are imperative to move science education standard forward to meet the global education challenges. Modebelu, (2007) in support of the above, indicated that majority of these teachers who lacked competence were as a result of inadequate remuneration and substantial professional development. Garner (2005) agreed that a good percentage of teachers (scientists) lacked desired competency for imparting science education.

\subsection{Teachers are under motivated to teach science because they do not understand how existing it} is:

Okebukola (2006) reported that teachers already consider science to be one of the contemporary fields of study and that attempts to transfer the excitement of science through lectures give teachers the opportunity to experience the thrill of doing science themselves instead of presenting science as a purview of the elite. Okeke, (2009) noted that

\begin{abstract}
programmes that combine "science excitement lectures" with "hands on" experiments usually re-reinforce unproductive attitudes. For example, hands on" activities should be "do-it-yourself" or "cook-book"demonstration of under graduate. This type of laboratory should be in a sharp contrast to inquiries, which give teachers opportunities for real openended scientific discoveries. It should be noted that in "real science" the answer is never simple, singular, stable or in many case even know.
\end{abstract}

When the focus of science education was changed from science content to science process the hesitation of teachers to teach science greatly diminished.

\subsection{Supplementary teacher training is necessary because few teachers especially in the junior secondary have been required to take science classes in college:}

Research has shown that a teacher with adequate materials, enough time, good classroom and science experiment management skills can actually provide their students with an excellent science education with remarkable little science content knowledge. This agreed with Bower and Pine 
(2009) finding that the more college science courses the teachers have taken, the more likely they should be to model their teaching on the lecture based approach science professions.

\subsection{The problem with science education is lack of good curriculum and therefore we must develop} it:

This implies that there is no good readily available inquiry-based curriculum. It has been observed that it is much easier to reform a curriculum than to develop a new curriculum.

Gardner (2005) emphasiszed that curriculum development is much more costly and time consuming. It also requires long term revision, field testing and evaluation by a highly talented, motivated and educated development team.

\subsection{The key to scientists' involvement with teacher training is to provide complex information in as digestive a form as possible.}

This indicated that disturbing simplified scientific information is about the last thing a scientists should do. Watered down lectures only serve to reinforce in teachers, the sense of incapability of understanding scientific principles, reinforcing the insecurity that many teachers already feel about science. It is also noted that "classroom management" skills required to organize time and materials or help students work in cooperative groups are not something that most scientists know anything about. However, what scientists seem to know about is how to conduct investigations.

\section{How Science Education Can be used to Attain Sustainable Development}

A better education in science for your child can also mean better things for the society by helping students develop into more responsible citizens who help to build a strong economy, contribute to a healthier environment, and bring about a brighter future for everyone.

The more science-literate individuals are, the stronger their society can be. Specifically, the lessons and skills science gives us can have effects that help make for more responsible citizens, a strong economy, a healthier environment, and a brighter future for everyone.

\subsection{Producing More Responsible Citizens}

Students who have learned to think critically and have a healthy dose of skepticism can better make their own, informed decisions, which can make them more enlightened, informed voters and stronger consumers. Also, the sense of responsibility and caution that science provides - along with the understanding of how things work (be they chemical reactions, human development, or nutritional needs) - can help future parents to provide safe, healthy environments for their own children, and be more responsible pet owners and neighbors.

\subsection{Helping To Build a Strong Economy}

The communication, research, reporting, and collaboration skills that science provides can produce a generation of individuals who are better prepared for any career and can make greater contributions to society. Also, students who have a solid knowledge base in science will later be more open to emerging technologies and ideas that can boost businesses and stimulate the economy. It has been noted that the difference between developed and developing countries is based on the quantity and quality of science and technology they possess (Ochu, 2007). Adikwu ( 
2008) maintained that, if Nigeria must survive as a nation we need science and technology used and managed by Nigerians.

\subsection{Contributing to a Global Health}

Scientific achievements have led to longer, healthier, better lives. A generation that understands and honors or celebrates past achievements will welcome and pave the way for future discoveries and inventions that will improve physical and mental health. And a healthier society means a more productive society.

\subsection{Contributing To Informed Decisions That Impact the World}

By emphasizing and explaining the dependency of living things on each other and on the physical environment, science fosters the kind of intelligent respect for nature that can inform decisions on the uses of technology to improve the world for humans and all living things.

\subsection{Ensuring Future Support of Scientific Research and Advancements}

A science-literate society will provide the necessary support, funding and promotion to ensure future generations continue to improve upon modern advances that benefit everyone. A society aware of the benefits of science will work to ensure it remains scientifically competitive.

\section{Challenges of a Sustainable Science Education}

\subsection{Funding}

The Success of any education depends largely on funding. This is because inadequate funding militates against the provision of quality education. It adequately affects provision of infrastructure, facilitiesd and needed number of teachers.

Nwangwu (2004): reported that ill equipped workshops, libraries and laboratories exist because of serious shortfalls and inadequacies in education funding.

\subsection{Lack of instructional materials}

Instructional materials are facilities, equipment or materials that the teacher uses to illustrate, emphasize and explain the lessons for better comprehension by the students. Efanga (2005) maintains that the availability and use of instructional materials have significant effect on the performance of the pupils/students.

UNESCO (2000) equally stated that instructional materials are important in the actualization of the curriculum. Some aspects of science are full of some abstract concepts which pose problems to the students in their understanding. Availability and use of instructional materials in teaching such difficult concepts will make for better understanding and thus enhance achieve the objectives of science education.

\subsection{Large class size:}

Teacher - pupil ratio is a very big challenge to science teachers of science education. According to the objectives of science education. According to the Federal Republic of Nigeria (FRN, 2004), the teacher - pupil ratio should be 1:35. This is contrary to the 1:60 most schools have in the south- 
east. For science teachers to carry out their teaching very well, they should be able to encourage the pupils positively, show love, recognize individual differences and plan cooperative teaching with the pupils. The large number of pupils under the control of the teacher incapacitates and create interactional gap between the teacher and the learners. The type and quality of interaction that exists in the classroom does not only determine the effectiveness of teaching and learning situation but also the attitudes, interest and even the personality of learners (Mbakwe, 2005).

\subsection{Remuneration and improved work conditions of science teachers:}

It is a known fact that optimal working condition for teachers directly contribute to the good quality of public education (Igbuzor, 2006). It is necessary for the government to rehabilitate and restore the image of science teachers. This could be done by enhancing teachers' packages. Science teachers' housing, accommodation and utility allowances should be increased. Transfer allowances should be paid to teachers who go on transfer and those who dwell in rivervrine and rural areas to perform their duties should be given special allowances to motivate teachers.

\subsection{Teaching methodology}

Methods are means that teachers use to drive home their lesson presentation thereby making learning experiences concrete to learners. Mbakwe (2005) affirms that methodology of teaching is what makes a teacher a professional. The old method only presents learners as mere spectators listening and swallowing all that comes from the teachers. For proper achievement of the objectives of science by the learners the teachers should provide learners with basic knowledge, values and skills and with some degree of freedom allow learners to initiate and complete learning with some degree of freedom to allow learners to initiate and complete learning with minimal interference.

\subsection{Political Instability}

Rarely in the history of Nigeria have the demands of democracy and the needs of economy been so closely aligned. It is in the nation's best interest that democracy is sustained and allowed to flourish. Sustaining the country's democracy is vital to maintaining political stability, to consolidating the market economy, to regaining and sustaining international investors' confidence in the country, and to strengthening its position as an emerging economy.

\section{The Roles of Science Teachers in the Sustainable Development of Science Education}

Teachers are the builders of the nation. Science teachers create various opportunities for students to engage in doing activities that will enable them make sense of the world around them, make new discoveries, solve interesting problems and develop skills that are sustainability driven. Omoifo (2012) emphasized that science teachers therefore, need to recognize the nature of scientific endeavours and how it relates to science teaching if they are to help their students completely understand the content and underlying principles of science. Effective and consistent implementation of the science and technology curriculum will lead to poverty alleviation, increase in productivity and rapid economic growth. This will surely reduce the capital flight incurred on importation of goods.

Science teachers are increasingly realizing the necessity to become agent of change in order to better meet the needs of students, families and communities they serve and thus fulfill society's expectations about science educators' civil responsibility. Science teachers play crucial role in 
shaping the students' mind towards sustainability as they impart the knowledge of science. Science teachers help to develop sustainability skills for students such as

- Mastery of subject matter in science'

- Motivating students to learn science

- Psychomotor skills

- Facilitating team work

- Becoming skilled personnel

\section{Prospects of Science Education}

The efforts on ground for the improvement of science education for a better tomorrow are

- The establishment of more universities and colleges of education with specification for minimum academic standards would solve the problem of both professional teacher supply and quality of instruction. With enough teachers large class size will be effectively handled.

- The science equipment centers already established in some parts of the country would provide enough standardized equipment for effective delivery of instruction and for the laboratories.

- Research results on the effects of innovative teaching styles and better ways of improving our curricular delivery would equip the teachers to better fulfill their roles.

\section{Conclusion}

The development of any nation depends directly on its level of scientific literacy. Science education if fully implemented will accelerate the sustainable development of Nigeria by providing the bedrock upon which technological advancement of the nation is built. It is the hope of the writers that when the problems listed are addressed sustainable development will be achieved in the nation.

\section{Recommendations}

- Government and private sectors should put in more effort and resources towards the development of science education.

- Government should also provide necessary science research equipment in the research institutes so that Nigerian scientists can carry out research work without tears especially as regards to the economy of the country.

- More science laboratories should be established and the few existing ones equipped and staffed so that students can have enough facilities to research on.

- Qualitative and affordable science education should be made available for all.

- More modern learning aids such as computers, internet, web sites facilities, over head projectors, internet web sites facilities, overhead projectors, firms etc. should be provided in schools.

- Science teachers should be well paid so that they can put in their best in teaching the students.

\section{References}

Adikwu, M.U. (2008). Curriculum Development in Science, Technology and Mathematics (STM) Education Keynote address presented at the $49^{\text {th }}$ annual conference of Science Teachers Association of Nigeria, Minna, August. 
Bower, J.M \& Pine B. (2009). Science Education Reform: Myths, Method And Madness. Caltech Precollege. Science Institution California: Caltech Precollege Science Institution.

Gardner, D.P (2005). A Nation at Risk: Imperative For Education Reform. The National Commission on Excellence in Education, U.S Dept of Education, Washington, D.C April 1983 Ed. 22600.

Federal Republic of Nigeria (2004). National Policy on Education. Lagos :NERDC press.

Lewis, A. (1985). Science Teaching In Africa. London:Heineman Educational Book Ltd.

Nada, T. (2008): The Reality Of Innovation In Government: Http:/Www.Innovation Peer-Revie Reality $P d f$.

Mbarjiorgu, N.M (2003). Science the Teachers Perspective (An Introduction To Science Education). Enugu Institute of Development Studies UNEC.

Modebelu, M.N. (2007). Strategies For Improving Teaching Profession And Teachers' Commitment In Secondary Schools In Nigeria. Journal of Educational Management and Policy (JOEM).2 (1).

Momeke, C. O. (2007). 'Effects of the learning cycle and Expository instructional approaches on students' learning outcome in secondary Biology' An unpublished Ph.D thesis submitted to the school of post graduate studies, University of Benin, Benin City.

Ochu, A.N.O. (2007). Evaluation of Undergraduates Chemistry Education Programme in the Universities in North Central Education Zone in Nigeria. Unpublished Ph.D thesis, University of Nigeria, Nsukka.

Ogunleye A.O (2007). Building A Sustainable Science. Curriculum In Nigeria: Accommodating Local Adaptation Areas Of Improvement For Quantity Assurance. Proceedings of $50^{\text {th }}$ Annual National Conference of Science Education Books (Nigeria) Plc.

Ogunmade, T.O (2006). And Quality of Secondary Science Teaching and Learning of Secondary Science Teaching And Learning Of Secondary In Lagos State, Nigeria. An UnpublishedDoctoral Thesis, Edith Cowan University, Perth, Western Australia.

Okeke, O.C (2009). Training Science For Capacity. A Paper Presented For Anambra State STANLuncheon And Award At Choice Hotel Awka, July 30.

Okebukola, P. (2006). Principles and policies guiding reforms in Nigerian Universities./HEA/RESA; council for development.

Omoifo, C. N. (2012). Dance of the limits - reversing the trends in scienceeducation in Nigeria. Inaugural Lecture Series 124, Benin City: University of Benin Press.

Onah, A.O. (2003). Science Education and Poverty Eradication in Nigeria" Eha -Amufu School of Education Journal 3(1).

Pember, S. T. \& Humbe, T. T. (2009). Science Education and National Development. Being a paper presented at the ASSUTIBS Maiden National Conference at CEO Katsina- Ala $6^{\text {th }}-9^{\text {th }}$ October. 
